\title{
Fabrication of Ag nanoparticles adhered on RGO based on both electrodes in dye-sensitized solar cells (DSSCs)
}

\author{
Kongsak Pattarith ${ }^{{ }^{*}}$ and Yonrapach Areerob ${ }^{2}$
}

\begin{abstract}
The electrode plays an important role in dye-sensitized solar cells (DSSCs). Preparation of the electrode should be simple and should result in high performance of its DSSC. We herein demonstrated high-performance and easily prepared Silver nanoparticles adhered on Reduced graphene oxide-Platinum composites (Ag-RGO/Pt) as counter electrodes (CEs) and $\mathrm{TiO}_{2}$ on $\mathrm{RGO}$ sheets with $\mathrm{Ag}\left(\mathrm{TiO}_{2}-\mathrm{RGO} / \mathrm{Ag}\right)$ as photoanode (PE) in DSSCs. The 1:2 Ag-RGO/Pt $\mathrm{CE}$ and $0.5 \% \mathrm{TiO}_{2}-\mathrm{RGO} / \mathrm{Ag}$ PE showed an overall highest power conversion efficiency of $9.15 \%$ under (1.5 AM) solar irradiation. The optimal weight ratio of Ag:RGO:Pt materials was also examined. Moreover, we showed that incorporation of Ag nanoparticles into the counter electrode successfully improved interfacial charge transfer resulting in high electrocatalytic activity for the reduction of triiodide to iodide redox, which in turn could enhance the performance of the DSSCs.
\end{abstract}

Keywords: Dye-sensitized solar cells, Counter electrode, Reduced graphene oxide, Silver

\section{Introduction}

Energy is an integral part of human civilization. Throughout history, we have utilized various sources of energy, some of which are hard to replenish and will likely have been exhausted in the future. These include fossil fuels such as petroleum, natural gas and coal. To solve the ever more pressing energy crisis, scientists have studied sustainable alternatives from sources like water and wind as well as from geothermal and solar sources, with solar energy being used as a primary source of renewable energy (Chang et al. 2010). Dye-sensitized solar cells (DSSCs) are a class of photovoltaic (PV) technology devices of interest owing to their low cost, non-toxicity, flexibility and impressive photovoltaic performance (Daniel et al. 2010). A typical conventional DSSC comprises a dye-sensitized semiconductor (typically $\mathrm{TiO}_{2}$, $\mathrm{ZnO}$ ) as the photoanode, a redox electrolyte that consists

\footnotetext{
${ }^{*}$ Correspondence: kongsak.pr@bru.ac.th

${ }^{1}$ Department of Chemistry, Faculty of Science, Buriram Rajabhat University, Buriram 31000, Thailand

Full list of author information is available at the end of the article
}

of $\mathrm{I}_{3}{ }^{-} / \mathrm{I}^{-}$as a redox couple and a back electrode called counter electrode (CE) (Guo et al. 2012). Among them, the electrode plays an important role in achieving high conversion efficiency. The ideal electrode material should provide high catalytic activity, high surface area and good electrical conductivity, as the primary role of the $\mathrm{CE}$ is to collect the electrons from the external circuit and regenerate the redox couple of the electrolyte ensuring cyclic operation of DSSCs (Tan et al. 2013). Moreover, at the heart of the DSSC structure is the photoanode prepared with mesoporous semiconducting material. The PE plays a significant role in collection of electrons from photoexcited dye molecules and also determines the amount of dye adsorption, which depends on surface area, crystallinity and morphology (Murugadoss et al. 2019).

Graphene is a two-dimensional nanostructure which has received a tremendous interest for a wide range of applications. It has been intensively studied for its use as transparent conducting electrodes due to its high transparency, great surface area $\left(2630 \mathrm{~m}^{2} / \mathrm{g}\right)$, electron transfer mobility $\left(15,000 \mathrm{~cm}^{2} / \mathrm{V} \mathrm{s}\right)$ as well as electrochemical activities. In DSSCs, graphene derivatives are 
used in various ways, for example as transparent electrodes, counter electrodes, electron donor/acceptor, and also as a light absorber for enhancing the power conversion efficient (PCE) by effective utilization of visible light, and also to suppress the recombination process of photo-generated electrons. In 2014, Menga and coworkers (Menga et al. 2013) prepared Pt-graphene electrodes and studied their DSSC performance. To maximize the photo-to-electron conversion efficiency of DSSCs, graphene sheets were mixed with platinum (Pt) to form a composite and to enhance the electrochemical property (Murugadoss et al. 2019). The energy conversion efficiency of about $4.23 \%$ was obtained. There result showed that $\mathrm{Pt}$-graphene was a promising material for the counter electrode of DSSC. In addition, the poor dye adsorption in 1-D $\mathrm{TiO}_{2}$ nanostructures could be addressed by modifications of the photoanode with graphene-based materials. Some researcher had done a systematic study with incorporation of graphene sheets (GS) in $\mathrm{TiO}_{2}$ NPs, and observed that the PCE of the GS- $\mathrm{TiO}_{2}$ was five times higher than that of the $\mathrm{TiO}_{2}$ NPs alone (Wang et al. 2015). The enhanced performance was due to better dye loading in the GS- $\mathrm{TiO}_{2}$ composite film than that of the bare $\mathrm{TiO}_{2}$ film. These properties significantly improved the dye intake and electron mobility over photoanodes. Their investigations provided a scope for improving the PCE of DSSCs based on $1 \mathrm{D}-\mathrm{TiO}_{2}$ nanostructures with the graphene derivatives and have led to a scientific curiosity for understanding fundamental processes like carrier generation and transportation process within $\mathrm{RGO}-\mathrm{TiO}_{2}$ nanotube composites (R-TNT-Cs) (Krishnamurthy and Namitha 2013).

It is well known that one promising strategy to improve chemical and electronic properties of the CE material is to incorporate some noble metallic nanoparticles such as $\mathrm{Au}$ or $\mathrm{Ag}$ into the counter electrode of DSSCs due to their regeneration from $\mathrm{I}_{3}^{-}$to $\mathrm{I}^{-}$sites and continuous path for electron movement, which reduces the charge transfer resistance of the device (Peng et al. 2013). Many reports show that there is enhanced electrocatalytic performance for Ag-based photoanode material in DSSCs application. Gupta et al. doped $\mathrm{TiO}_{2}$ prepared by a modified sol-gel method with $1 \% \mathrm{Ag}$ and used it as a DSSC photoelectrode. They found that the electron lifetime of the Ag-doped photoelectrode was smaller than that of the undoped photoelectrode. This Ag-doping increased the solar conversion efficiency of the photoelectrode from 2.75 to $5.66 \%$. Simultaneously, Ag nanoparticles could act as an efficient electron acceptor when combined with $\mathrm{TiO}_{2}$ owing to the well-known metal-semiconductor heterojunction, which would restrain charge recombination so as to improve the interfacial charge transfer in the DSSCs (Singh et al. 2019). However, less publication about the applicability of $\mathrm{Ag}$ nanoparticle adhere on RGO-Pt is reported (Wang et al. 2015).

Hence, in this study, we report the synthesis of $\mathrm{Ag}$ nanoparticles-adhered RGO-Pt composites (Ag-RGO/ $\mathrm{Pt}$ ) as counter electrodes and $\mathrm{TiO}_{2}-\mathrm{RGO} / \mathrm{Ag}$ as photoanode by the hydrothermal method, and their application in DSSCs. We have explored optimal weight ratio conditions of Ag:RGO:Pt and $\mathrm{TiO}_{2}: \mathrm{RGO}: \mathrm{Ag}$ on the composite material compared with conventional materials (Pt) under identical experimental (1.5 A.M) condition. As expected, the addition of $\mathrm{Ag}$ nanoparticles improves the power conversion efficiency of the DSSCs greatly. Moreover, the effect of cell preparation by double-screen printing is also discussed.

\section{Methods}

\section{Chemicals and characterization}

Graphite powder, concentrated sulfuric acid, hydrogen peroxide and potassium permanganate were purchased from Sigma-Aldrich Chemical Co., Ltd. Korea. Titanium (III) chloride solution and silver nitrate were purchased from Sinopharm Chemical Reagent Co. Ltd (China). All the chemicals were used without any further purification. Morphological analysis of the prepared Ag-RGO/Pt was carried out using FE-TEM (JEOL JEM-2100F) and FEGSEM (JEOL JSM-7600F).

\section{Synthesis of reduced graphene oxide (RGO)}

In brief, $3 \mathrm{~g}$ of natural flake graphite was added into a solution of $360 \mathrm{~mL} \mathrm{H}_{2} \mathrm{SO}_{4}$ with $40 \mathrm{~mL} \mathrm{H}_{3} \mathrm{PO}_{4}$ and then $18 \mathrm{~g}$ of $\mathrm{KMnO}_{4}$ was slowly added under stirring at $10{ }^{\circ} \mathrm{C}$ for $24 \mathrm{~h}$. Afterward, $400 \mathrm{~mL}$ of deionized water and $20 \mathrm{~mL}$ of $30 \mathrm{wt} \% \mathrm{H}_{2} \mathrm{O}_{2}$ solution were successively dropped into the aforementioned solution. Graphene oxide (GO) powder was then collected after centrifugation, washed several times with $30 \%$ aqueous $\mathrm{HCl}$ solution, ethanol, then deionized water, and freeze-dried. After freeze-drying, $1 \mathrm{~g}$ of GO was added into a solution of $100 \mathrm{~mL}$ deionized water under ultrasonication. Then, $5.00 \mathrm{~mL}$ of hydrazine hydrate was added into the prepared solution and refluxed at $100-120^{\circ} \mathrm{C}$ for $24 \mathrm{~h}$. The resulted rGO as a black solid was filtered and washed with water and ethanol, respectively, then dried in vacuum desiccator at $80{ }^{\circ} \mathrm{C}$ (Krishnamurthy and Namitha 2013).

\section{Synthesis of silver-adhered reduced graphene oxide (Ag- RGO)}

Silver-adhered reduced graphene oxide; (Ag-RGO) was synthesized via a simple method (Peng et al. 2013). First, $1 \mathrm{~g}$ of silver nitrate $\left(\mathrm{AgNO}_{3}\right)$ was dissolved in ammonia $\left(\mathrm{NH}_{3}\right)(2.3 \mathrm{~mL})$. This solution was further diluted in DI 
water $(50 \mathrm{~mL}) .3 .5 \mathrm{~mL}$ of $\mathrm{GO}$ with a concentration of $1 \mathrm{~g} / \mathrm{L}$ was added to the solution. Then, $5.00 \mathrm{~mL}$ of hydrazine hydrate was added into the prepared solution, which was then refluxed at $100-120^{\circ} \mathrm{C}$ for $24 \mathrm{~h}$. Ag-RGO black solids were washed by ultrapure water and ethanol several times. Finally, Ag-RGO sheet was dried at room temperature overnight.

\section{Synthesis of silver-adhered reduced graphene oxide- platinum (Ag-RGO/Pt) for counter electrode}

To prepare Ag-RGO/Pt solution to get the Pt:RGO:Ag ratio of 2:1, 1:1, 1:2,1:3 v/v, which would be referred to as (2:1) Ag-RGO/Pt, (1:1) Ag-RGO/Pt, (1:2) Ag-RGO/Pt and (1:3) Ag-RGO/Pt, respectively, firstly, $0.5 \mathrm{~mL}$ of $\mathrm{Ag}-$ $\mathrm{RGO} / \mathrm{Pt}$ was mixed with $4 \mathrm{~g}$ of terpinol, $0.5 \mathrm{~g}$ of ethylcellulose and $9 \mathrm{~g}$ of anhydrous ethanol. The Ag-RGO/ Pt paste was then spread onto FTO glass via the screen printing technique (Yuan et al. 2012). The Ag-RGO/Pt film was subsequently annealed at $450{ }^{\circ} \mathrm{C}$ for $30 \mathrm{~min}$ in air.

\section{Synthesis of silver-adhered reduce graphene oxide- titanium dioxide $\left(\mathrm{TiO}_{2}-\mathrm{RGO} / \mathrm{Ag}\right)$}

The optimized $\mathrm{TiO}_{2}-\mathrm{Ag}$ samples prepared were then wrapped by a thin layer of RGO by solution mixing. The $\mathrm{TiO}_{2}-\mathrm{Ag}$ powder was dispersed in $100 \mathrm{~mL}$ of toluene and then mixed with $50 \mathrm{~mL}$ of GO solution for $12 \mathrm{~h}$ under UV light irradiation to convert the GO into RGO. The preparation conditions of all samples are summarized in Table 3. The $\mathrm{TiO}_{2}$ and $\mathrm{TiO}_{2}-\mathrm{RGO}$ were also characterized for comparison purposes. This sample was also characterized for comparison.

\section{Preparation of $\mathrm{TiO}_{2}$-modified photoanode and fabrication of DSSC}

The $\mathrm{TiO}_{2}$ modified photoanode was prepared as follows. Initially, $100 \mathrm{mg}$ of $\mathrm{TiO}_{2}-\mathrm{RGO} / \mathrm{Ag}$ nanoparticles (NPs) was taken to a mortar and pestle and gently ground for 10 min with $2 \mathrm{~mL}$ of ethyl alcohol. Then, $\mathrm{TiO}_{2}-\mathrm{RGO} /$ Ag slurry was coated on FTO substrates. These films were then sintered at $450{ }^{\circ} \mathrm{C}$ for $60 \mathrm{~min}$. Then, the sintered mesoporous films were soaked in a solution having $0.3 \mathrm{mM}$ N719 dye for $24 \mathrm{~h}$ at an ambient temperature to adsorb dye molecules. This dye-adsorbed mesoporous $\mathrm{TiO}_{2}$ film was used as the photoanode. DSSCs were assembled by sandwiching the $\mathrm{TiO}_{2}-\mathrm{RGO} / \mathrm{Ag}$ photoanode and Ag-RGO/Pt-based CE. A Surlyn spacer (gasket) of $\sim 60 \mathrm{~mm}$ was placed between the electrodes. A drop of $\mathrm{I}^{-} / \mathrm{I}_{3}{ }^{-}$based liquid electrolyte was introduced into the spacer area till the space was homogeneously filled with the liquid as shown in Fig. 1 (Muthoosamy et al. 2015).

\section{Results and discussion Characterization}

The morphologies of graphite, graphene oxide (GO), reduced graphene oxide (RGO) and silver-adhered reduced graphene oxide (Ag-RGO) were characterized by SEM analysis. An SEM micrograph of graphite is shown in Fig. 2a. Predominantly, the morphology of graphite appears as unevenly sized flakes. Figure $2 b$ shows the flake-like and irregular morphological structures of graphene oxide. After reduction by hydrazine

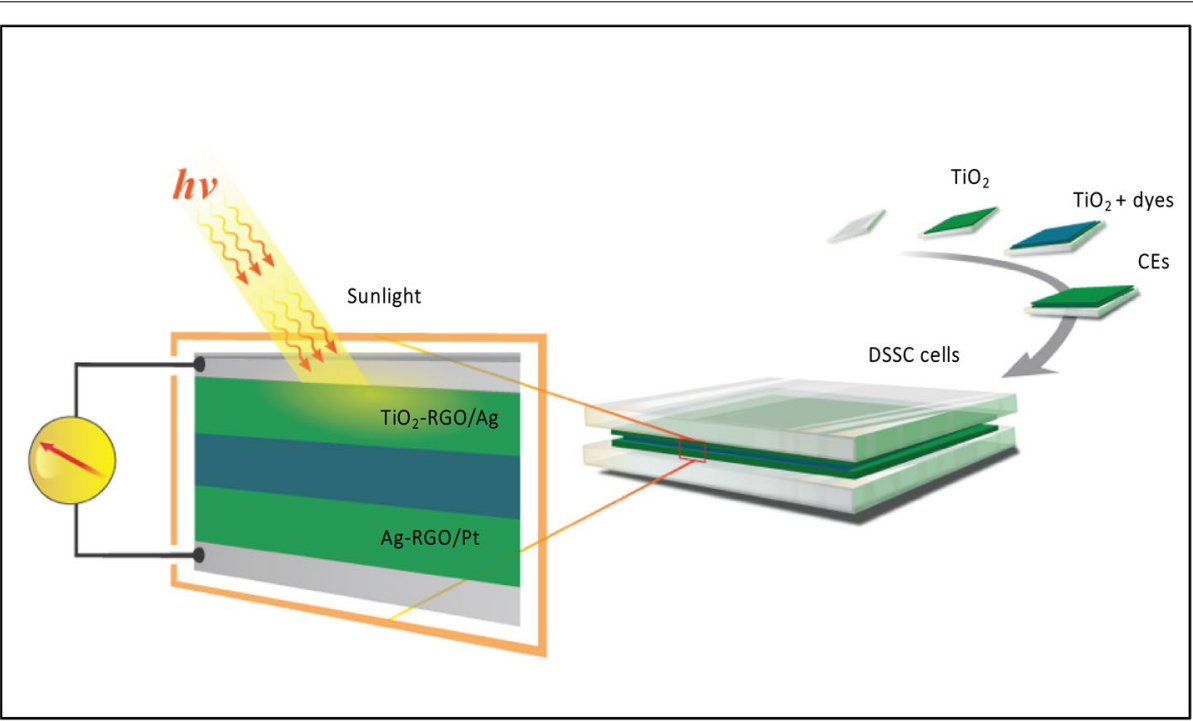

Fig. 1 Schematic diagram for counter electrode prepared 

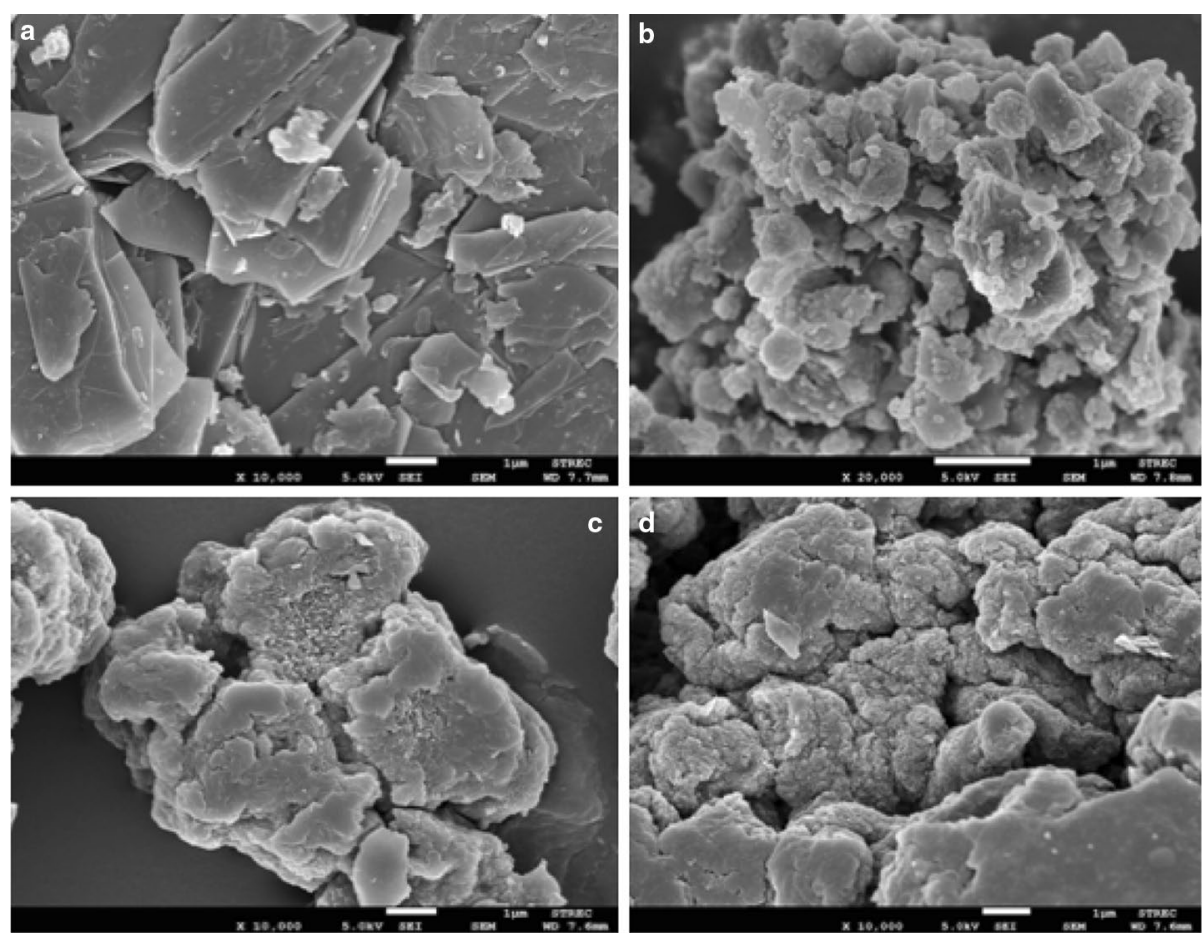

Fig. 2 SEM micrographs of $\mathbf{a}$ graphite, $\mathbf{b}$ graphene oxide, $\mathbf{c}$ reduced graphene oxide and $\mathbf{d}$ silver-adhered reduced graphene oxide

hydrate, RGO agglomeration formed (Fig. 2c) as a result of the oxygenic groups on the GO surface being removed leading to a decrease in the distance between layers of the GO (Hsieh et al. 2013). Moreover, the attachment of Ag nanoparticles to the RGO sheets is observed (Fig. 2d). (More information was showed in Additional file 1).

As can be seen in Fig. 3a, irregularly shaped nanoparticles with the average size of ca. $40 \mathrm{~nm}$ of $\mathrm{TiO}_{2}$ are observed. In addition to the nanoparticles of $\mathrm{TiO}_{2}$, lamellar RGO is also found in the $\mathrm{TiO}_{2}-\mathrm{RGO}$ sample, as shown in Fig. 3 b. $\mathrm{TiO}_{2} \mathrm{NSs}$ are wrapped with another surface of $\mathrm{RGO}$, the introduction of which leads to the disappearance of the large Ag particles (Fig. 3c). The particles all become smaller on the surface of RGO, which may be due to electrostatic properties between the negatively charged RGO and the positively charged $\mathrm{Ag}^{+}$. To confirm the loading of $\mathrm{Ag}$ NPs on the surface of the RGO sheets, TEM imaging was performed. TEM images of AgNPs/RGO nanocomposite are shown in Fig. 4a, b. It can be observed that $\mathrm{Ag}$ nanoparticles are evenly distributed and well dispersed on the surface of the GO sheets. The mean diameter of the AgNPs is $25.01 \mathrm{~nm}$ as calculated from Nano Measurer based on the random statistics of 100
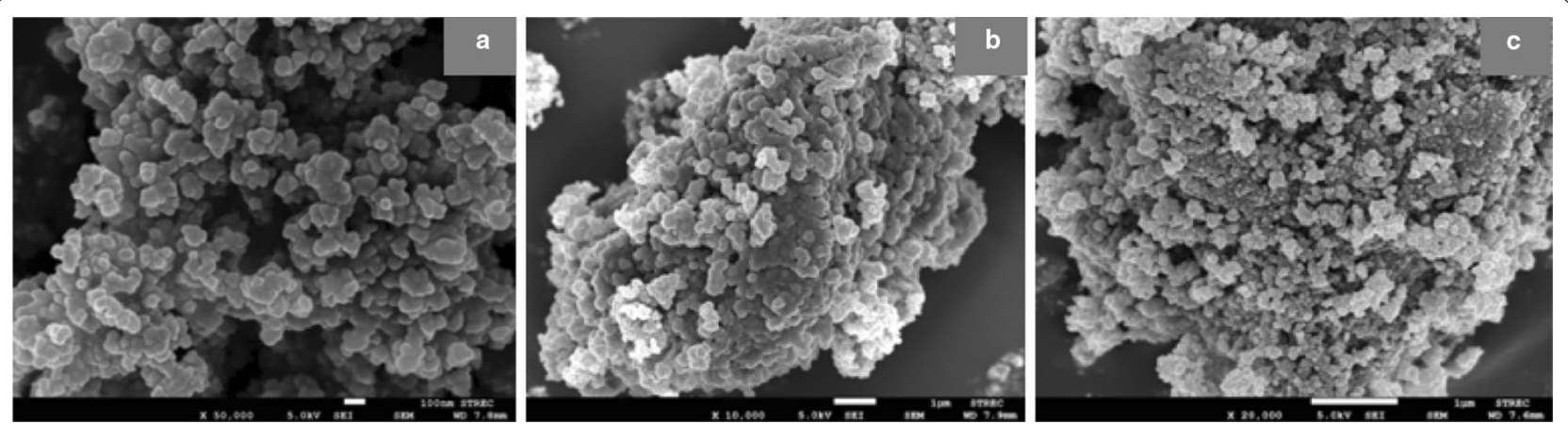

Fig. 3 SEM micrographs of $\mathbf{a} \mathrm{TiO}_{2}, \mathbf{b} \mathrm{TiO}_{2}-\mathrm{RGO}$ and $\mathbf{c} \mathrm{TiO}_{2}-\mathrm{RGO} / \mathrm{Ag}$ 

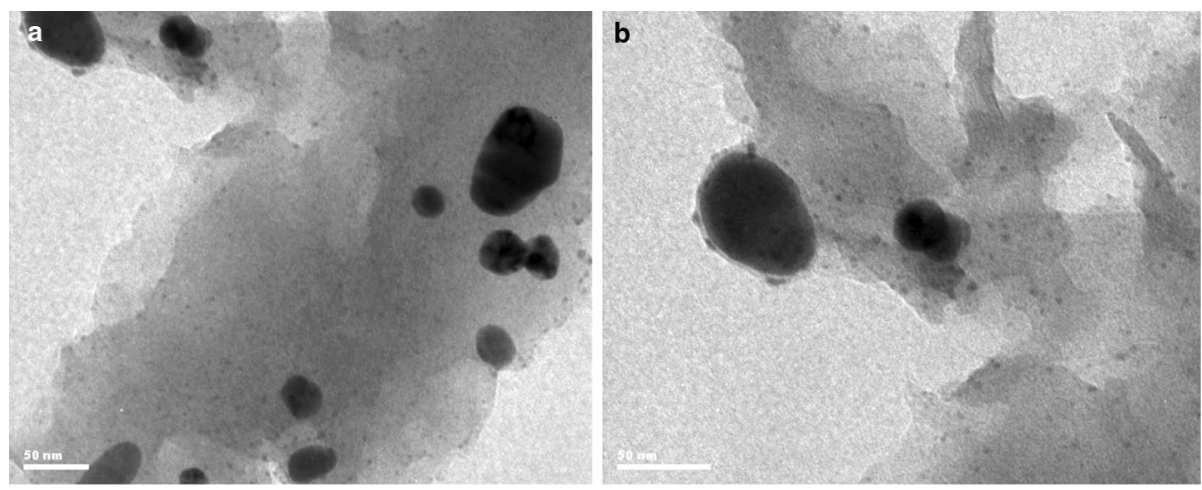

Fig. 4 a, b TEM images of AgNP/RGO nanocomposites
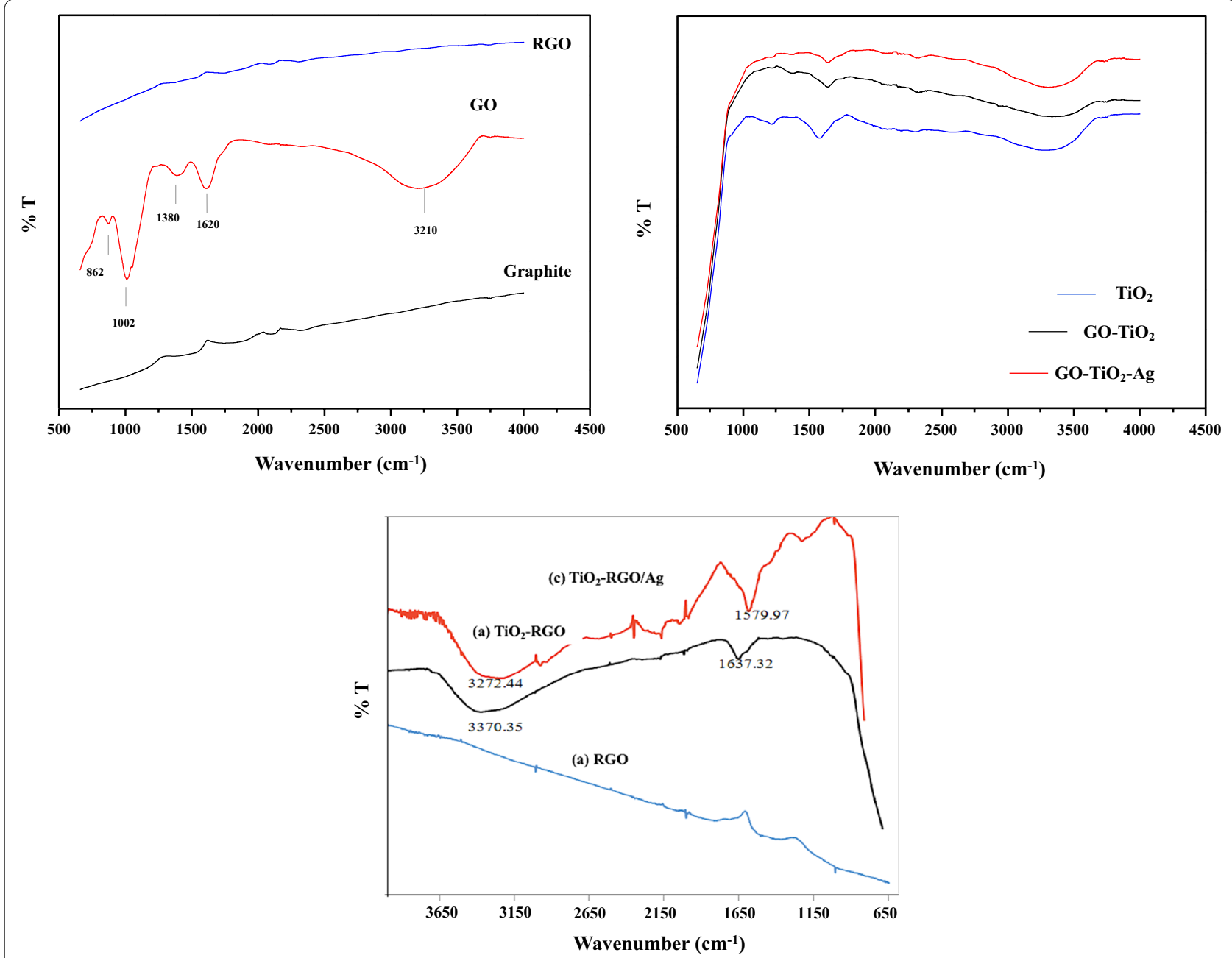

Fig. 5 ATR-IR of all samples 
AgNPs. The TEM images also confirm the crystallinity of silver and RGO in the Ag-RGO (Singh et al. 2018; Tang et al. 2012).

Figure 5a exhibits the FTIR spectra of GO and Ag/ RGO nanostructures. In the spectrum of GO, the relatively broad peak at $3402 / \mathrm{cm}^{-1}$ arises from the stretching vibration of $-\mathrm{OH}$ of absorbed water and the carboxyl group. The absorption bands at $1739 / \mathrm{cm}$ and $1404 / \mathrm{cm}^{-1}$ can be attributed to the $\mathrm{C}=\mathrm{O}$ stretching vibration of carboxyl group and the deformation vibration of O-H, respectively. The weak peaks at $1227 / \mathrm{cm}^{-1}$ and $1050 / \mathrm{cm}^{-1}$ can be interpreted as the epoxy $(\mathrm{C}-\mathrm{O})$ and alkoxy $(\mathrm{C}-\mathrm{O})$ groups located around the edges of the GO nanosheets. Meanwhile, the sharp peak at $1625 / \mathrm{cm}^{-1}$ also confirms the presence of adsorbed water and the aromatic $\mathrm{C}=\mathrm{C}$ originating from the skeletal vibrations of unoxidized graphitic domains (Zhua et al. 2014). As for Ag/RGO, most of the above-mentioned characteristic peaks are absent. In addition, the significantly decreased intensity around $3400 / \mathrm{cm}^{-1}$ evidences the reduction of oxygen-containing groups and the absorption band at $1562 / \mathrm{cm}^{-1}$ can be attributed to the skeletal vibration of the graphene sheets. Moreover, the peak at $1166 / \mathrm{cm}^{-1}$ is attributed to the $\mathrm{C}-\mathrm{OH}$, indicating that the hydroxyl group is difficult to be completely removed and suggesting that there is a strong interaction between the $\mathrm{Ag}$ particles and the hydroxyl groups (Cao et al. 2018; Beranek and Kisch 2008).

Figure 5b showed the FTIR analysis of the $\mathrm{TiO}_{2}-$ RGO/Ag nanocomposites. The FTIR results show many powerful absorption peaks which correspond to different functional groups of oxygen such as water $\mathrm{OH}$ stretching $\left(2950 / \mathrm{cm}^{-1}\right)$, water $-\mathrm{OH}$ bending group, $\mathrm{C}=\mathrm{C}$ stretching group $\left(1642 / \mathrm{cm}^{-1}\right)$, alcoholic $\mathrm{C}-\mathrm{OH}$ bending $\left(1390 / \mathrm{cm}^{-1}\right)$, phenolic $\mathrm{C}-\mathrm{O}-\mathrm{H}$ stretching or epoxide $\mathrm{C}-\mathrm{O}-\mathrm{C}\left(1250 / \mathrm{cm}^{-1}\right)$, and $\mathrm{C}-\mathrm{O}$ stretching $\left(1100 / \mathrm{cm}^{-1}\right)$. In addition, the significant wide peaks ranging between 400 and $800 / \mathrm{cm}$ indicate the stretching vibration of $\mathrm{Ti}-\mathrm{O}-\mathrm{Ti}$ bonds in the crystalloid $\mathrm{TiO}_{2}$ nanocomposites. The significant shifting in the obtained results for $\mathrm{TiO}_{2}-\mathrm{RGO}$ composites in the absorption peaks intensity, which correspond to the functional groups of oxygen, indicates that more water and hydroxyl groups are surface adsorbed. This may play an important role in the photocatalytic oxidation reaction due to the effective reduction of GO (Hasan et al. 2015). Moreover, the optical properties of the nanoparticles were studied using Systronics UV-Visible spectrometer 2202. Figure 6 shows the absorbance of the sample in nano-range at room temperature. The spectrum between 200 and $1200 \mathrm{~nm}$ was studied. It shows a peak at $354 \mathrm{~nm}$ wavelength with absorbance

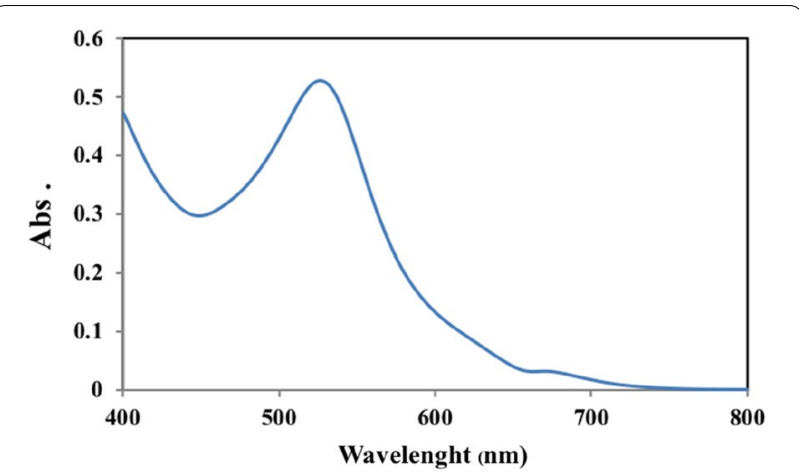

Fig. 6 UV-Visible absorption spectrum of $\mathrm{TiO}_{2}$ nanoparticles

of $0.86(<1)$, which means that it exhibits good absorbance within the UV region.

\section{Photovoltaic performance Counter electrodes}

The DSSC performance was measured under sun illumination (1.5 AM) conditions for each of these counter electrodes (Fig. 7). The obtained cell parameters of the short-circuit current $\left(U_{\mathrm{sc}}\right)$, open-circuit voltage $\left(V_{\mathrm{oc}}\right)$, fill factor (FF) and PCE are summarized in Table 1. From Table 1 , the energy conversion efficiency $(\eta)$ of the RGO is $1.27 \%$, which is lower than that of the Pt-based CE $(6.08 \%)$ due to the poor catalytic property for $\mathrm{I}_{3}{ }^{-}$reduction and high sheet resistance (Lee et al. 2007). However, the percentage ratio of the energy conversion efficiency of the Pt:RGO (1:1) is 6.63\% compared to that of the Pt $\mathrm{CE}$, which indicates that an appropriate molar ratio of $\mathrm{Pt}$ and RGO can increase the efficiency of the DSSCs. The power conversion efficiency increases to $6.63 \%$ after the addition of Pt due to the increased number of active sites for triiodide reduction and electrical conductivity (Murugadoss et al. 2017; Tang et al. 2010).

In addition, Table 1 shows the cells conversion efficiency after adding $\mathrm{Ag}$ in the $\mathrm{Ag}-\mathrm{RGO} / \mathrm{Pt}$ nanocomposite. The Ag-RGO/Pt (1:2) gives a $J_{\mathrm{sc}}$ of $17.20 \mathrm{~mA} / \mathrm{cm}^{2}$ and $\eta$ of $7.72 \%$, which is much higher than the cells prepared without Ag. This is because Ag acts as an electron transfer catalyst and has excellent electrical conductivity. Besides, numerous randomly distributed functional groups on GO surface can furnish a large number of nucleation sites for $\mathrm{Ag}$ ions, so as to ensure the homogeneous distribution of $\mathrm{Ag}$ particles and improve the conversion efficiency and chemical stability of the cells (Dwivedi et al. 2017). 

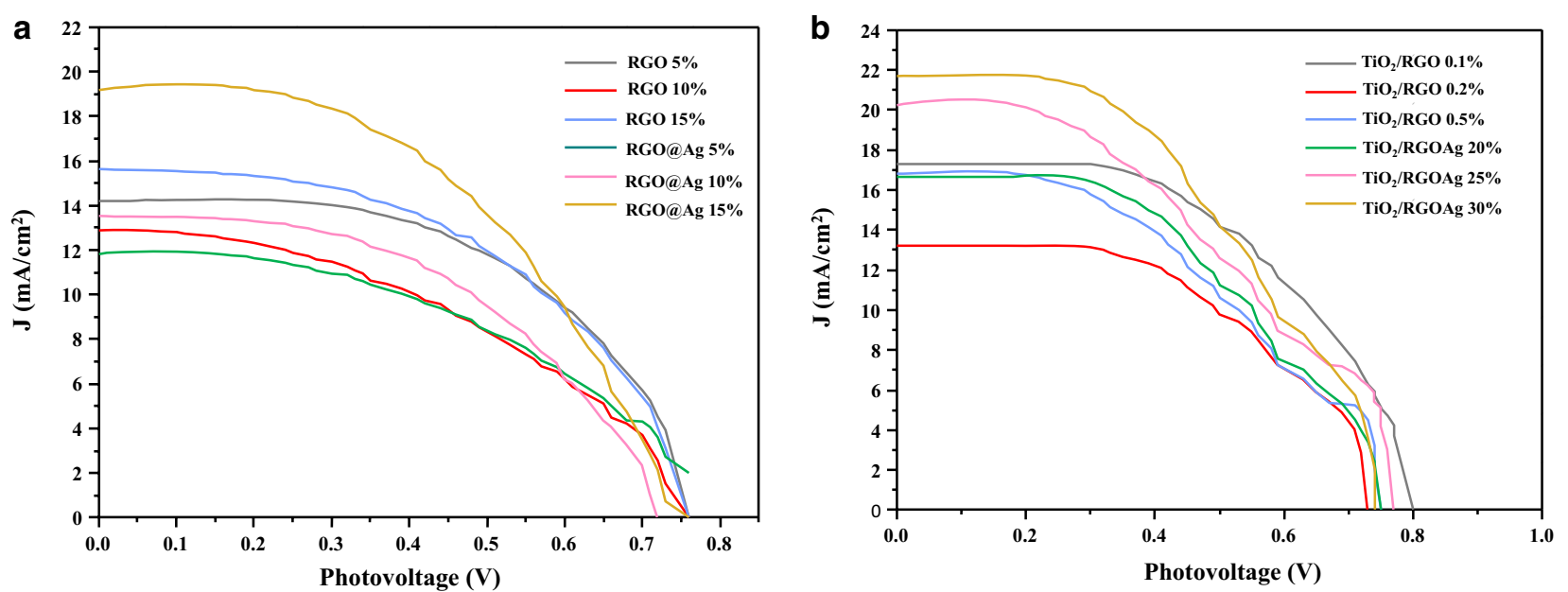

Fig. 7 J-V characteristics of different (a) counter electrodes and (b) different photoanodes in DSSC

Table 1 Photovoltaic parameters of the different CEs in DSSC

\begin{tabular}{llllll}
\hline Samples & $\boldsymbol{V}_{\mathbf{o c}}(\mathbf{V})$ & $\boldsymbol{J}_{\mathbf{s c}}\left(\mathbf{m A} / \mathbf{c m}^{\mathbf{2}}\right)$ & $\mathbf{F F}$ & $\boldsymbol{\eta}$ (\%) & S.D. \\
\hline Pt & 0.80 & 13.40 & 0.57 & 6.08 & 0.14 \\
RGO & 0.78 & 4.70 & 0.35 & 1.27 & 0.03 \\
Pt:RGO (2:1) & 0.79 & 14.60 & 0.48 & 5.51 & 0.25 \\
Pt:RGO (1:1) & 0.79 & 16.26 & 0.51 & 6.63 & 0.11 \\
Pt:RGO (1:2) & 0.79 & 14.56 & 0.51 & 5.84 & 0.13 \\
Pt:RGO (1:3) & 0.81 & 17.15 & 0.36 & 5.06 & 0.24 \\
RGOAg & 0.79 & 10.59 & 0.34 & 2.81 & 0.27 \\
Pt:RGOAg (1:1) & 0.77 & 17.28 & 0.45 & 5.95 & 0.16 \\
Pt:RGOAg (1:2) & 0.78 & 17.20 & 0.58 & 7.72 & 0.21 \\
Pt:RGOAg (1:3) & 0.77 & 17.47 & 0.41 & 5.51 & 0.12 \\
\hline
\end{tabular}

\section{Photoanode electrodes}

The results of different anodes of pure $\mathrm{TiO}_{2}, \mathrm{TiO}_{2}-\mathrm{RGO}$ and $\mathrm{TiO}_{2}-\mathrm{RGO} / \mathrm{Ag}$ nanocomposites under simulated sun light (1.5 AM, $\left.100 \mathrm{~mW} / \mathrm{cm}^{2}\right)$ are shown in Fig. 8 and Table 2. The fill factor of DSSC with pure $\mathrm{TiO}_{2}$ anode is 0.80 and with $(0.10 \% \mathrm{w} / \mathrm{w}) \mathrm{TiO}_{2}-\mathrm{RGO}$ it is 0.81 , which indicates that the introduction of graphene into $\mathrm{TiO}_{2}$ film has negligible effect on the FF. The increase in graphene concentration causes a down shift in conduction band of the $\mathrm{TiO}_{2}-\mathrm{RGO}$ nanocomposites with respect to pure $\mathrm{TiO}_{2}$ resulting in a slight decrease in $V_{\mathrm{oc}}$. The electron transfer in a DSSC photo electrode can be divided into two steps (a) excited electrons from the dye molecules to the conduction band of $\mathrm{TiO}_{2}$ and (b) electrons from $\mathrm{TiO}_{2}$
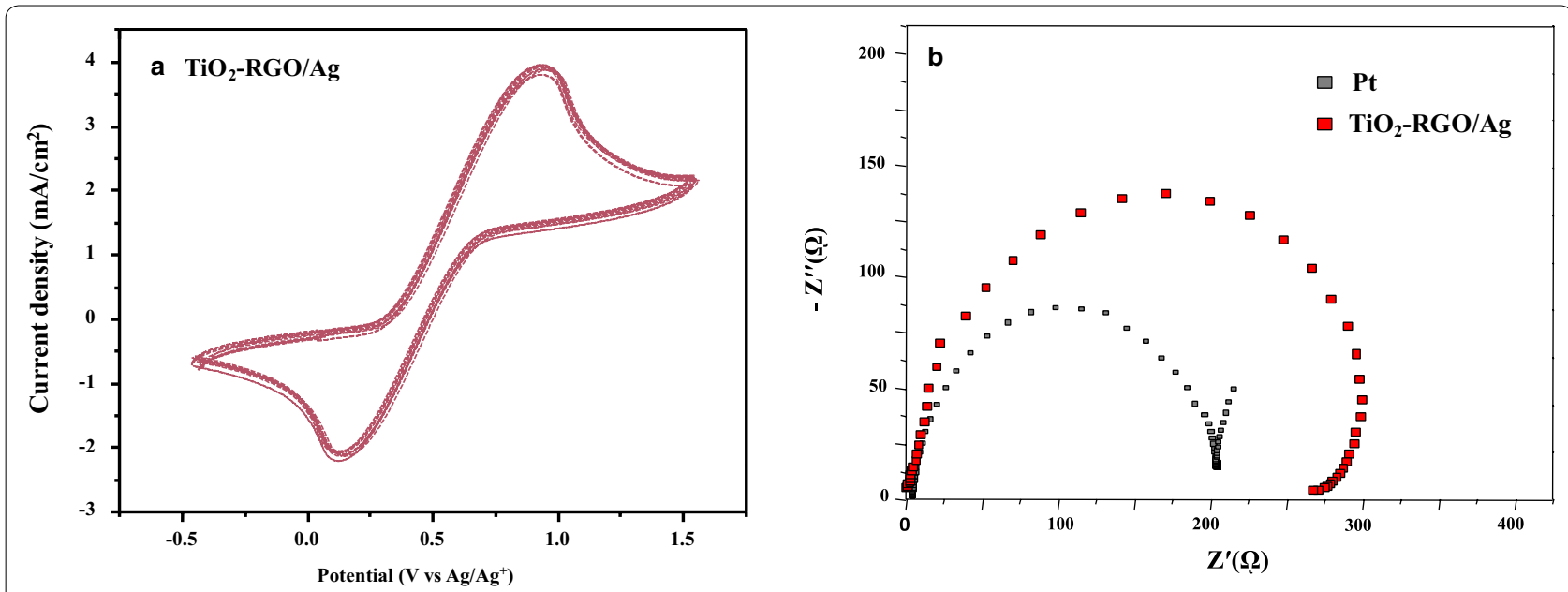

Fig. 8 Cyclic voltammetry and Nyquist plot of $\mathrm{TiO}_{2}-\mathrm{RGO} / \mathrm{Ag}$ 
Table 2 Photovoltaic parameters of the difference PEs in DSSCs

\begin{tabular}{|c|c|c|c|c|c|}
\hline $\mathrm{RGO}: \mathrm{TiO}_{2}(\% \mathrm{w} / \mathrm{w})$ & $V_{\text {oc }}(\mathrm{V})$ & $J_{s c}\left(m A / c^{2}\right)$ & $\mathrm{FF}$ & $\eta(\%)$ & S.D. \\
\hline Standard cell & 0.80 & 13.40 & 0.57 & 6.08 & 0.14 \\
\hline 0.01 & 0.80 & 10.23 & 0.80 & 6.57 & 0.05 \\
\hline 0.05 & 0.80 & 12.10 & 0.74 & 7.20 & 0.08 \\
\hline 0.10 & 0.81 & 14.00 & 0.77 & 8.79 & 0.10 \\
\hline 0.50 & 0.81 & 15.66 & 0.47 & 5.98 & 0.06 \\
\hline 1.00 & 0.82 & 15.72 & 0.45 & 5.77 & 0.10 \\
\hline 5.00 & 0.73 & 15.42 & 0.51 & 5.67 & 0.22 \\
\hline 10.00 & 0.74 & 10.58 & 0.61 & 4.75 & 0.16 \\
\hline 15.00 & 0.69 & 12.03 & 0.42 & 3.46 & 0.09 \\
\hline RGOAg: $\mathrm{TiO}_{2}(\%)$ & $V_{\text {oc }}(\mathrm{V})$ & $J_{s c}\left(\mathrm{~mA} / \mathrm{cm}^{2}\right)$ & $\mathrm{FF}$ & $\eta(\%)$ & S.D. \\
\hline 5 & 0.76 & 12.59 & 0.53 & 5.06 & 0.11 \\
\hline 10 & 0.81 & 13.22 & 0.48 & 5.10 & 0.08 \\
\hline 15 & 0.77 & 11.41 & 0.69 & 6.06 & 0.13 \\
\hline 20 & 0.83 & 16.89 & 0.46 & 6.49 & 0.20 \\
\hline 25 & 0.82 & 18.51 & 0.46 & 6.96 & 0.14 \\
\hline 30 & 0.87 & 15.54 & 0.53 & 7.12 & 0.19 \\
\hline 40 & 0.82 & 13.12 & 0.55 & 5.98 & 0.14 \\
\hline 50 & 0.84 & 9.46 & 0.72 & 5.78 & 0.22 \\
\hline
\end{tabular}

to photo-electrode determines the power conversion efficiency of the DSSC (Saranya et al. 2016; Guai et al. 2012). Due to the excellent electrical conductivity of graphene sheets, they can act as bridges to accelerate electron transfer from $\mathrm{TiO}_{2}$ to the photo electrode, which reduces the possibility of electron hole recombination. Graphene in the DSSC has a significant influence on the number of ejected electrons transferred from the photoanode to the counter electrode causing an increase in $J_{\mathrm{sc}}$. As a result, the power conversion efficiency of the DSSC is enhanced.

Moreover, that the $J_{\mathrm{sc}}$ increases from 5.10 to $7.12 \mathrm{~mA} /$ $\mathrm{cm}^{2}$ leads to an increase in PCE from 5 to $50 \%$ with $\mathrm{TiO}_{2}-\mathrm{RGO} / \mathrm{Ag}$ NCs. The improvement in $J_{\mathrm{sc}}$ and PCE is a result of enhanced light absorption by dye molecules due to the surface plasmon resonance (SPR), which is sensitive optical technique for monitoring biomolecular binding events via detection refractive index changes on metal NCs. From these observations, we believe that the corrosion of Ag NCs is not the major reason for the deterioration of the plasmonic cell performance; the reference device itself is not very stable due to high corrosive electrolyte and some other reasons (Salam et al. 2015). It is also well known that DSSCs based on ruthenium dyes are not very photostable. The dye can also degrade due to the adsorption of water on the active $\mathrm{TiO}_{2}$ surface. This process can detach the dye molecules from photoanodes resulting in the severe reduction in the conversion efficiency of the DSSC.
Moreover, we confirm the catalytic properties by $\mathrm{CV}$ and EIS measurement as shown in Fig. 8. From the Cyclic voltammetry, the stability of $\mathrm{TiO}_{2}-\mathrm{RGO} / \mathrm{Ag}$ is analyzed for a scan rate of $20 \mathrm{mV}$ for 10 cycles. The uniform shape of the curve delivers a stable redox activity, which further confirms the excellent electrochemical stability for electrode. In addition, we measured cells series resistance by electrochemical impedance spectroscopy (EIS). The $\mathrm{TiO}_{2}-\mathrm{RGO} / \mathrm{Ag}$ showed lower resistance than $\mathrm{Pt}$, which can show higher performance.

\section{The preparation of electrodes of $\mathrm{TiO}_{2}-\mathrm{RGO}$ and $\mathrm{TiO}_{2}-$ RGOAg}

This experiment is bringing the results from the topic, which gives the highest efficiency in each of the verses to compare and bring together new cells so that the cells have higher efficiency, the results of which can be shown as Table 3. From Table 3, it was found that solar cells using $\mathrm{TiO}_{2}-\mathrm{RGO}(0.1 \% \mathrm{RGO})$ are anode electrodes and $\mathrm{RGO} / \mathrm{Pt}$, ratio $1: 1$ and Pt:RGOAg, ratio $1: 2$, are cathode electrodes (Tripathi et al. 2014). The light energy conversion efficiency is 8.796 .81 and $9.15 \%$, respectively, which are all higher than the standard cell used in this research. The maximum is $50.49 \%$ because the anode and cathode electrodes are both effective in helping transfer. Better electrons within the solar cell cause the anode electrode to pass through the electron to the external circuit quickly; while the cathode electrodes pass through electrons to the electrolyte solution as well, thereby reducing 
Table 3 The efficiency of the cells prepared with the most effective electrodes

\begin{tabular}{|c|c|c|c|c|c|c|}
\hline Anode & Cathode & $V_{\text {oc }}(\mathrm{V})$ & $J_{s c}\left(m A / c^{2}\right)$ & $\mathrm{FF}$ & $\eta(\%)$ & S.D. \\
\hline $\mathrm{TiO}_{2}$ & Pt & 0.80 & 13.40 & 0.57 & 6.08 & 0.14 \\
\hline $\mathrm{TiO}_{2}$ & Pt:RGO, 1:1 & 0.79 & 16.26 & 0.51 & 6.63 & 0.11 \\
\hline $\mathrm{TiO}_{2}$ & Pt:RGOAg, $1: 2$ & 0.78 & 17.20 & 0.58 & 7.72 & 0.21 \\
\hline $\mathrm{TiO}_{2} / \mathrm{RGO} 0.1 \%$ & Pt & 0.81 & 14.00 & 0.77 & 8.79 & 0.10 \\
\hline $\mathrm{TiO}_{2} / \mathrm{RGO} 0.2 \%$ & Pt:RGO, 1:1 & 0.81 & 13.81 & 0.61 & 6.81 & 0.25 \\
\hline $\mathrm{TiO}_{2} / \mathrm{RGO} 0.5 \%$ & Pt:RGOAg, 1:2 & 0.78 & 14.30 & 0.82 & 9.15 & 0.11 \\
\hline $\mathrm{TiO}_{2} / \mathrm{RGOAg} 20 \%$ & Pt & 0.87 & 15.54 & 0.53 & 7.12 & 0.19 \\
\hline $\mathrm{TiO}_{2} / \mathrm{RGOAg} 25 \%$ & Pt:RGO, 1:1 & 0.87 & 17.50 & 0.46 & 7.00 & 0.16 \\
\hline $\mathrm{TiO}_{2} / \mathrm{RGOAg} 30 \%$ & Pt:RGOAg, 1:2 & 0.85 & 17.42 & 0.51 & 7.53 & 0.17 \\
\hline
\end{tabular}

Table 4 Anode cell preparation by double-screen screen printing

\begin{tabular}{llllll}
\hline Anode cells $\left(\mathrm{TiO}_{\mathbf{2}}\right)$ & $\boldsymbol{V}_{\text {oc }}(\mathbf{V})$ & $\boldsymbol{J}_{\mathbf{s c}}\left(\mathbf{m A} / \mathbf{c m}^{2}\right)$ & FF & $\boldsymbol{\eta}$ (\%) & S.D. \\
\hline $\mathrm{TiO}_{2}$ & 0.80 & 13.40 & 0.57 & 6.08 & 0.14 \\
$\mathrm{TiO}_{2} / \mathrm{RGOAg}$ & 0.81 & 16.30 & 0.50 & 6.57 & 0.18 \\
$\mathrm{TiO}_{2} / \mathrm{RGO}$ & 0.73 & 6.03 & 0.73 & 3.18 & 0.16 \\
$\mathrm{RGO} / \mathrm{TiO}_{2}$ & 0.74 & 3.06 & 0.57 & 1.30 & 0.03 \\
$\mathrm{RGOAg} / \mathrm{TiO}_{2}$ & 0.82 & 3.12 & 0.35 & 0.88 & 0.27 \\
\hline
\end{tabular}

the aggregation of the charge at the electrode resulting in increased efficiency of solar cells.

For solar cells measurement, $\mathrm{TiO}_{2}-\mathrm{RGOAg}(30 \%$ RGOAg) act as anode electrode and Pt:RGO, ratio 1:1 and Pt:RGOAg, ratio 1:2 act as cathode electrode. The efficiency of light energy conversion into electrical energy equal to $7.12,7.00$ and $7.53 \%$ for $\mathrm{TiO}_{2} / \mathrm{RGOAg}$ $25 \%$ and $\mathrm{TiO}_{2} / \mathrm{RGOAg} 30 \%$, respectively, which are all higher than the efficiency of the standard cells used in this research. The highest is $23.84 \%$ when comparing the efficiency of solar cells using $\mathrm{TiO}_{2}-\mathrm{RGO}(0.1 \% \mathrm{RGO})$ and $\mathrm{TiO}_{2}-\mathrm{RGOAg}$ (RGOAg 30\%) is an anode electrode using Pt:RGOAg at a ratio of 1:2 to a cathode electrode (Zhang et al. 2011). It is found that electrodes using $\mathrm{TiO}_{2}-\mathrm{RGO}$ have higher cell efficiency than electrodes that use $\mathrm{TiO}_{2}-\mathrm{RGOAg}$.

\section{The effect of cell preparation by double-screen screen printing}

The energy conversion efficiency is the electrical energy of solar cells that is prepared by two layers of screen between $\mathrm{TiO}_{2} / \mathrm{RGO}$, and $\mathrm{TiO}_{2} / \mathrm{RGOAg}$ for act as anode electrode and the Pt act as cathode electrode, which is shown in Table 4. From Table 4, when preparing cells by screening in two layers, the $\mathrm{TiO}_{2}-\mathrm{RGOAg}$ cells will be $\mathrm{TiO}_{2}$ coated as the first layer, and then the RGOAg code is the second layer. It was found that the cells that obtained the light energy conversion efficiency were 6.57 , $3.18,1.30$ and $0.88 \%$, respectively. The highest power conversion efficiency of the cell was prepared by two layers of anode (Wang et al. 2016; Liu and Kuo 2013). The first layer was $\mathrm{TiO}_{2}$ followed by the second layer, the RGOAg, which has the efficiency of converting light energy into electrical energy equal to $6.57 \%$ with $V_{\text {oc }}$ value equal to 0.81 . The $J_{\mathrm{sc}}$ and FF value are $16.30 \mathrm{~mA} / \mathrm{cm}^{2}$ and 0.50 , respectively which shown the highest of energy conversion efficiency about $8.06 \%$.

\section{Conclusion}

In conclusion, we have successfully fabricated $\mathrm{Ag}$ nanoparticles-adhered RGO/Pt composites (Ag-RGO/Pt) for counter electrode and $\mathrm{TiO}_{2}$-modified $\mathrm{RGO} / \mathrm{Ag}$ for photoanode in dye-sensitized solar cells (DSSCs). The power conversion efficiency of $0.5 \% \mathrm{TiO}_{2}-\mathrm{RGO} \mathrm{PE}$ and (1:2) $\mathrm{Ag}-\mathrm{RGO} / \mathrm{Pt} \mathrm{CE}$ is $9.15 \%$ is higher than that of the convince Pt CE. The enhanced performance of the DSSC with RGO is due to the improvement in dye loading, improved electronic conductivity for the photo-generated charge carriers and the prevention of the electronhole pair recombination process. The addition of Pt and Ag nanoparticles to the electrodes can increase surface area and catalytic activity, which can in turn improve power conversion efficiency. In particular, the DSSC performance of the $\mathrm{Ag}-\mathrm{RGO} / \mathrm{Pt} \mathrm{CE}$ is superior to that of the Pt electrodes commonly used in DSSCs.

\section{Supplementary information}

Supplementary information accompanies this paper at https://doi. org/10.1186/s40807-020-00058-3.

Additional file 1. Additional figures. 


\section{Acknowledgements}

This work was supported by Department of Chemistry, Faculty of Science, Buriram Rajabhat University, Buriram 31000, Thailand.

\section{Authors' contributions}

YA participated in the fabrication and photoelectrochemical characterization of the DSSCs, and drafted the manuscript and the revision process. KP participated in the development of the software design, calibration and measurement the photoelectrochemical properties of DSSCs under homemade solar simulator. All authors read and approved the final manuscript.

\section{Funding}

Not applicable, or no funding was received.

\section{Availability of data and materials}

Not applicable.

\section{Competing interests}

The authors declare that they have no competing interests.

\section{Author details}

${ }^{1}$ Department of Chemistry, Faculty of Science, Buriram Rajabhat University, Buriram 31000, Thailand. ${ }^{2}$ Department of Advanced Materials Science \& Engineering, Hanseo University, Seosan-si, Chungcheongnam-do 31962, South Korea.

Received: 30 July 2019 Accepted: 11 February 2020 Published online: 03 March 2020

\section{References}

Beranek, R., \& Kisch, H. (2008). Tuning the optical and photoelectrochemical properties of surface-modified $\mathrm{TiO}_{2}$. Photochemical \& Photobiological Sciences., 7, 40-48.

Cao, H., Xie, Y., Feng, Q., Wang, H., Wang, X., Xu, Z., et al. (2018). Multifunctional catalysts with high catalytic activities: Flower-like $\mathrm{Co}_{9} \mathrm{~S}_{8}$ microballs assembled with weak crystalline pea pod-shaped nanowires. International Journal of Hydrogen Energy, 43, 18832.

Chang, H., Wang, G., Yang, A., Tao, X., Liu, X., Shen, Y., et al. (2010). A transparent, flexible, low-temperature, and solution processible graphene composite electrode. Advanced Functional Materials, 20, 2893-2902.

Daniel, R. D., Park, S., Christopher, W. B., \& Rodney, S. R. (2010). The chemistry of graphene oxide. Chemical Society Reviews, 39, 228-240.

Dwivedi, P., Das, S., \& Dhanekar, S. (2017). Wafer-scale synthesized MoS2/Porous Silicon nanostructures for efficient and selective ethanol sensing at room temperature. ACS Applied Materials \& Interfaces, 9, 37662.

Guai, G. H., Song, Q. L., Guo, C. X., Lu, Z. S., Chen, T., Ng, C. M., et al. (2012). Graphene-Pt/ITO counter electrode to significantly reduce Pt loading and enhance charge transfer for high performance dye-sensitized solar cell. Solar Energy, 86, 2041-2048.

Guo, Y., Sun, X., Liu, Y., Wang, W., Qiu, H., \& Gao, J. (2012). One pot preparation of reduced graphene oxide (RGO) or Au (Ag) nanoparticle-RGO hybrids using chitosan as a reducing and stabilizing agent and their use in methanol electrooxidation. Carbon, 50, 2513-2523.

Hasan, R., Hamid, S. B., Basirun, W. J., Chowdhury, Z. Z., Kandjani, A. E., \& Suresh, K. B. (2015). Ga doped RGO-TiO, composite on an ITO surface electrode for investigation of photoelectrocatalytic activity under visible light irradiation. New Journal of Chemistry, 39, 369-376.

Hsieh, C., Lin, C., Chen, Y., Lin, J., \& Teng, H. (2013). Silver nanorods attached to graphene sheets as anode materials for lithium-ion batteries. Carbon, 62, 109-116.

Krishnamurthy, G., \& Namitha, R. (2013). Synthesis of structurally novel carbon micro/nanospheres by low temperature-hydrothermal process. Journal of the Chilean Chemical Society, 58, 1930-1933.

Lee, K., Suryanarayanan, V., \& Ho, K. (2007). A study on the electron transport properties of $\mathrm{TiO}_{2}$ electrodes in dye-sensitized solar cells. Solar Energy Materials and Solar Cells, 91, 1416-1420.

Liu, B., \& Kuo, H. (2013). Graphene/Silver nanowire sandwich structures for transparent conductive films. Carbon, 63, 390-396.
Menga, X., Shao, X., Li, H., Liu, F., Pu, X., Li, W., et al. (2013). One-step hydrothermal synthesis characterization and visible-light catalytic property of Ag-reduced graphene oxide composite. Materials Research Bulletin, 481, 453-1457.

Murugadoss, V., Arunachalam, S., Elayappan, V., \& Angaiah, S. (2019a). Development of electrospun PAN/CoS nanocomposite membrane electrolyte for high-performance DSSC. Ionics, 24, 4071-4080.

Murugadoss, V., Lin, J., Liu, H., Mai, X., Ding, T., Guo, Z., et al. (2017). Optimizing graphene content in NiSe/graphene nanohybrid counter electrode on boosting photovoltaic performance of dye-sensitized solar cells. Journal of Nanoscience and Nanotechnology, 17, 398-404.

Murugadoss, V., Panneerselvam, P., Yan, C., Guo, Z., \& Angaiah, S. (2019b). A simple one-step hydrothermal synthesis of cobalt-nickel selenide/graphene nanohybrid as an advanced platinum free counter electrode for dye sensitized solar cell. Electrochimica Acta, 312, 157-167.

Muthoosamy, K., Bai, R. G., Abubakar, I. B., Sudheer, S. M., Lim, H. N., Loh, H., et al. (2015). Exceedingly biocompatible and thin-layered reduced graphene oxide nanosheets using an eco-friendly mushroom extract strategy. International Journal of Nanomedicine, 10, 1505-1519.

Peng, S., Fan, X., Li, S., \& Zhang, J. (2013). Green synthesis and characterization of graphite oxide by orthogonal experiment. Journal of the Chilean Chemical Society, 58, 2213-2217.

Salam, Z., Vijayakumar, E., Subramania, A., Sivasankar, N., \& Mallick, S. (2015). Graphene quantum dots decorated electrospun $\mathrm{TiO}_{2}$ nanofibers as an effective photoanode for dye sensitized solar cells. Solar Energy Materials and Solar Cells, 143, 250-259.

Saranya, K., Subramania, A., Sivasankar, N., \& Mallick, S. (2016). Electrospun TiC embedded CNFs as a low cost platinum-free counter electrode for dyesensitized solar cell. Materials Research Bulletin, 75, 83-90.

Singh, N., Murugadoss, V., Nemala, S., Mallick, S., \& Angaiah, S. (2018). $\mathrm{Cu}_{2} \mathrm{ZnSnSe}{ }_{4}$ QDs sensitized electrospun porous $\mathrm{TiO} 2$ nanofibers as photoanode for high performance QDSC. Solar Energy, 171, 571-579.

Singh, N., Murugadoss, V., Rajavedhanayagam, J., \& Angaiah, S. (2019). A wide solar spectrum light harvesting $\mathrm{Ag}_{2} \mathrm{Se}$ quantum dot-sensitized porous $\mathrm{TiO}_{2}$ nanofibers as photoanode for high-performance QDSC. Journal of Nanoparticle Research, 21, 176.

Tan, L., Ong, W., Chai, S., \& Mohamed, A. (2013). Reduced graphene oxide-TiO, nanocomposite as a promising visible-light-active photocatalyst for the conversion of carbon dioxide. Nanoscale Research Letters, 8, 465

Tang, Y., Lee, C., Xu, J., Liu, Z., Chen, Z., He, Z., et al. (2010). Incorporation of graphenes in nanostructured $\mathrm{TiO}_{2}$ films via molecular grafting for dyesensitized solar cell application. American Chemical Society, 4, 3482-3488.

Tang, Y., Luo, S., Teng, Y., Liu, C., Xu, X., Zhang, X., et al. (2012). Efficient removal of herbicide 2,4-dichlorophenoxyacetic acid from water using Ag/ reduced graphene oxide $\mathrm{Co}$-decorated $\mathrm{TiO}_{2}$ nanotube arrays. Journal of Hazardous Materials, 241-242, 323-330.

Tripathi, B., Yadav, P., Pandey, K., Kanade, P., Kumar, M., \& Kumar, M. (2014). Investigating the role of graphene in the photovoltaic performance improvement of dye-sensitized solar cell. Materials Science and Engineering, 190, 111-118

Wang, Q., Li, Y., Sang, S., \& Jin, S. (2015). Effect of the reactivity and porous structure of expanded graphite (EG) on microstructure and properties of $\mathrm{Al}_{2} \mathrm{O}_{3}-\mathrm{C}$ refractories. Journal of Alloys and Compounds, 645, 388-397.

Wang, X., Xie, Y., Bateer, B., Pan, K., Zhou, Y., Zhang, Y., et al. (2016). Hexagonal FeS nanosheets with high-energy (001) facets: Counter electrode materials superior to platinum for dye-sensitized solar cells. Nano Research, 9, 2862.

Yuan, W., Gua, Y., \& Li, L. (2012). Green synthesis of graphene/Ag nanocomposites. Applied Surface Science, 261, 753-758.

Zhang, D. W., Li, X. D., Li, H. B., Chen, S., Sun, Z., Yin, X. J., et al. (2011). Graphenebased counter electrode for dye-sensitized solar cells. Carbon., 49, 5382-5388

Zhua, M., Li, X., Liu, W., \& Cui, Y. (2014). An investigation on the photoelectrochemical properties of dye-sensitized solar cells based on graphene-TiO, composite photoanodes. Journal of Power Sources, 262, 349-355.

\section{Publisher's Note}

Springer Nature remains neutral with regard to jurisdictional claims in published maps and institutional affiliations. 